\title{
Is Russia the emerging global “breadbasket”? \\ Re-cultivation, agroholdings and grain production
}

\author{
Oane Visser*, Max Spoor**, Natalia Mamonova***
}

* - Associate Professor, visser@iss.nl; ** - Professor, spoor@iss.nl, *** - PhD Candidate, mamonova@iss.nl. International Institute of Social Studies, The Hague of Erasmus University Rotterdam

\section{Introduction}

RUSSIA HAS SEEN A RECOVERY IN ITS AGRICULTURAL SECTOR since the early 2000s, which can particularly be noticed in the production and exports of wheat, which was at record height in the years 2008-2009. The re-emergence of Russia as a global grain producer is seen as potentially crucial in an increasingly tense and volatile global food market, in which food price hikes occurred in the periods 2007-2008, 2010-2011, and more recently in the second half of 2012. It is suggested that the country will become the new global "bread basket", in particular because large tracks of land, possibly 40-50 million hectares have been taken out of production since the early 1990s, and could be re-cultivated. A US Department of Agriculture (USDA) report (Liefert et al 2013, p. 19) projects that Russia's wheat production will grow by around 25 percent in the period till 2021, with export nearly doubling, and subsequently almost equalling the US as the World's largest wheat exporter (ibid, p. 21). The expectation is that this could positively contribute to resolving the global "food crisis". ${ }^{1}$

Production of wheat and coarse grains in Russia is dominated by large farm enterprises (LFEs), which are the successors of the previous kolkhozy and sovkhozy, with part of them currently merging into huge "megafarms" and enterprise conglomerates or "agroholdings". Financial capital penetrated the agribusiness sector since the mid-2000 and has caused a rapid process of financialisation of food and agricultural value chains. These agroholdings normally incorporate various LFEs, and often other firms in the agro-food chain (Visser et al. 2012). ${ }^{2}$

These large farm enterprises, and in particular the agroholdings, are increasingly seen in a positive light, suggesting that they are the ones responsible for the current "grain

\footnotetext{
${ }^{1}$ It is not suggested here that the "food crisis" is only caused by supply constraints, which is often argued. The effects of increased financialisation and speculation in food and agricultural markets, and unequal access to food are possibly even more important (Spoor \& Robbins 2012).

2 Due to the shady nature of the land transactions, the minimal or lack of compensation provided to land shareholders, and speculative motives to acquire large tracks of land (Visser \& Spoor 2011; Visser, Mamonova \& Spoor 2012), which characterise a substantial part of the land deals in the process of land concentration, they can be classified as 'land grabbing'.
} 
This is an Accepted Manuscript of an article published by Taylor \& Francis in Europe-Asia Studies on 11 Nov 2014, available online:

http://www.tandfonline.com/doi/abs/10.1080/09668136.2014.967569\#.VeCshPmqqko.To cite this article: Oane Visser, Max Spoor \& Natalia Mamonova (2014)

Is Russia the Emerging Global 'Breadbasket'? Re-cultivation, Agroholdings and Grain Production, Europe-Asia Studies, 66:10, 1589-1610

recovery", and the only way forward to solve the food crisis. In this article we investigate critically this proposition, and investigate whether large-scale farming, especially in the form of agroholdings with outside capital, and the associated land concentration, will indeed turn Russia into a global 'bread basket'.

We argue that this proposition is based on a number of incorrect assumptions: 1) that the impressive growth in wheat export indicates an equally drastic increase in production and yields; 2) that large stretches of abandoned land can be re-cultivated for wheat production without substantial economic and environmental costs; 3) that the expansion of megafarms and agroholdings in agriculture and the grain sector is a sign of their efficiency and potential to further increase wheat production; and 4) that higher wheat production directly leads to more exports.

In order to investigate the above-mentioned proposition and related assumptions, we will take into account various factors, such as efficiency, productivity, social and environmental costs of large-scale mode of production in the Russian context (e.g. de Schutter 2012; Deininger \& Byerlee 2011, for conflicting views). Although not all the necessary data is available, we will argue that this proposition is a misrepresentation of reality, and that the current return to Soviet belief in 'big is beautiful' under capitalist conditions will not be sustainable in the future.

In order to critically investigate the above-mentioned proposition, we will analyse grain production trends, the re-cultivation potential in particular for wheat, the importance and viability of agroholdings and megafarms in the grain sector, including the process of land concentration associated with it, and finally storage capacity, export potential and the effect of government policies increasingly focused on the livestock sector. Combining these elements will provide inputs to answer the question whether Russia is becoming a global 'bread basket' or not. The argument and article is structured as follows.

The second section will discuss wheat and grain production trends. The fact that Russia became the world's third wheat exporter in 2009 (just lagging behind the US and Canada), is often seen as proof of rapid, and ongoing, 'recovery' and promising potential of wheat production in Russia. This section will address the question whether wheat production has really recovered so much (for instance through growing yields) as the impressive export growth (although with large annual fluctuations) suggest.

The future role of Russia's wheat sector, apart from the regularly occurring bad harvests because of droughts, will particularly depend on whether the large potential that can be possibly re-cultivated in Russia (estimated at more than 40 million hectares) will actually be dedicated to wheat, as originally this land was largely cultivated with maize, rye, barley and oats. In section three, focussing on the re-cultivation potential, we will argue that the idea that all this abandoned land can be used for increasing wheat production profitably and without substantial environmental costs is not realistic. To get further insight in the potential of Russia as global breadbasket, we move from macro data on grain production and land use and land potential, to the enterprise or farm level.

In the fourth section we will briefly summarize the development of land reform and farm restructuring over the past two decades of post-Soviet transition, showing a continued dominance of large-scale agriculture in the form of the privatised successors of the kolkhozy and sovkhozy).

After this overview the fifth section will address the question: 'who produces grain in Russia?' It will discuss the role of private (peasant) farms versus large farm enterprises (LFEs), the privatised successors of the kolkhozy and sovkhozy. Within the latter category 
This is an Accepted Manuscript of an article published by Taylor \& Francis in Europe-Asia Studies on 11 Nov 2014, available online:

http://www.tandfonline.com/doi/abs/10.1080/09668136.2014.967569\#.VeCshPmqqko.To cite this article: Oane Visser, Max Spoor \& Natalia Mamonova (2014)

Is Russia the Emerging Global 'Breadbasket'? Re-cultivation, Agroholdings and Grain Production, Europe-Asia Studies, 66:10, 1589-1610

(which produces most of the grain), agroholdings have become increasingly important since the mid-2000s. We will depict the growth of these agroholdings in numbers, and their share in land and grain output.

In section six, we will zoom in on these agroholdings as supposed drivers of the growth in productivity and efficiency in the grain sector. Having shown in section three that the availability of economically (and environmentally) re-cultivable land is much more limited than expected, an increase in wheat yields is crucial for Russia to become a global 'bread basket' and to 'feed the World'. We will question whether these agroholdings are indeed so productive, profitable, efficient and successful as their rapid emergence suggests at first sight, and investigate whether they are the drivers of further growth in agriculture, and particularly the wheat sector. In this part of the analysis we will look at various issues such as productivity, profitability, and problems of management (in particular the problems related to the growing bureaucracies in these large corporate structures). We will add to the debate on agroholdings a crucial piece of analysis, namely that in spite of their generally "good press", in fact a substantial part of the agroholdings is in financial difficulties, or in a procedure of bankruptcy. These financial difficulties have occurred despite generous state support to agroholdings.

Section seven investigates the link between the 'recovery' in grain production and the potential for increased export, by looking at the infrastructure in the grain export chain, in particular the storage capacity. Alhough investments are currently undertaken in grain elevators and port facilities, the storage (and port) capacity is still a major constraint. We will argue that the large fluctuations in grain production in Russia, due to insufficient storage and transport capacity, tend to translate in strong price volatility in domestic and increasingly global markets, instead of contributing to global food security, with stable and accessible grain and bread prices.

In the final section we will conclude that the process of land, asset and financial capital concentration in the agricultural, and in particular in the grain sector in Russia is taking place at high speed. The country has substantial fertile land reserves and there is also a yield gap that can be reduced (World Bank 2011), which could lead to a strong expansion of particular wheat and coarse grains. The question is however whether this will really happen, and if so at what costs and with which benefits this new "food regime" (McMichael 2009) is further developing in Russia. Overall it seems unlikely that Russia will become the new global breadbasket, taking into account the costs of re-cultivating land reserves, the problems with large-scale production which is largely stimulated, and the limitations of Russia's export facilities.

\section{Grain production trends in Russia: real recovery?}

As stated before, Russia has recently become one of the main wheat exporters of the world. In 2009 it exported 16.8 million tons of wheat, while this was only slightly less than the world leaders in this market, namely Canada (with 19.3 million tons) and the US (with 21.9 million tons), the three countries together representing nearly 40 percent of the world wheat market (FAOSTAT 2013a). Russia did however export less wheat, 11.9 million tons (Ibid) in 2010 after drought and misharvests, with the government even installing an export ban (2010-11). ${ }^{3}$

\footnotetext{
${ }^{3}$ The fact that the export was still substantial in the years of the export ban, can be explained by the fact that the export ban in both 2010 and 2011 covered only part of those years.
} 
This is an Accepted Manuscript of an article published by Taylor \& Francis in Europe-Asia Studies on 11 Nov 2014, available online:

http://www.tandfonline.com/doi/abs/10.1080/09668136.2014.967569\#.VeCshPmqqko.To cite this article: Oane Visser, Max Spoor \& Natalia Mamonova (2014)

Is Russia the Emerging Global 'Breadbasket'? Re-cultivation, Agroholdings and Grain Production, Europe-Asia Studies, 66:10, 1589-1610

Since then, the country is strenuously gaining back its top position in the wheat export and in 2011 it exported 15.2 million tons (VLANT 2012), losing the third place to Australia.

These export figures are impressive, but has Russian wheat production really recovered, or even more, is it growing fast? Let us look more in detail to the available (and unfortunately not always consistent) data. In this case we used FAOSTAT data as our prime source, but realize that other sources such as RosStat (2013a) provide roughly similar but not always the same data. Three observations can be made while looking at the data from RosStat (2013a) presented in Table 1 First, there was a clear downward trend during the years 19901998, namely from 49.6 million tons to 27.0 million tons, although with fluctuations, troughs and peaks. These fluctuations are largely to be explained by the influence of recurrent droughts, which are estimated to occur once in four years, while also the disruption of the economy in the 1990s negatively influenced output, in particular through lower yields per hectare.

\section{[Table 1]}

Second, in the following decade, from 2000 to 2008 a clear upward trend is noticeable, with output increasing to even more than 60 million tons in 2008, although again with severe fluctuations and low output years because of droughts, such as in 2004 and 2006. However, the output level of the trough years of the 2000s is close to that of the peak years of the 1990s. In 2010 the worst drought in at least half a century occurred in Russia and caused a reduction in the wheat harvest to 41.5 million tons. Although 2011 was a successful year for Russian wheat production, with a harvest of 56.2 million tons, the drought of 2012 brought the country back to the figures of the mid-1990s, as wheat production appeared to be the lowest in the last 10 years, and amounted to only 37.7 million tons

Third, there is a clear upward trend in production of wheat, which is also in line with the decrease in imports and increase in exports. Indeed, already since 2002 Russia became an important exporter of wheat, with a total of 10.3 million tons (see Figure 1), with as main destinations the Middle East and North Africa (VLANT 2012).

\section{[Figure 1]}

With various fluctuations, following weak or strong output years, imports reduced to near zero levels, while exports were reported at around 10 - 15 million tons. The drought of 2010 gave rise to an export ban of the Russian government, which limited the export to 11.8 million tons of wheat for the 2010-11 post-harvest year. In 2011 Russian wheat exports rebounded to 15.2 million tons (VLANT 2012), and at the end of 2011 as in the previous year, Russia ranked fourth among the global wheat exporters, after the United States, Canada and Australia (Index Mundi 2013). ${ }^{4}$. Russia is expected to ship only 10 million tons of wheat in 2013-14 because of record-low stockpiles, according to Moscow-based consultancy SovEcon (Bloomberg 2013).

Fourth, the increase in production is a combined result of a small increase in harvested acreage and slightly improved yields. The total harvested area in 2008 and 2009 was more

\footnotetext{
${ }^{4}$ Somewhat different figures are given by VLANT (2012).
} 
This is an Accepted Manuscript of an article published by Taylor \& Francis in Europe-Asia Studies on 11 Nov 2014, available online:

http://www.tandfonline.com/doi/abs/10.1080/09668136.2014.967569\#.VeCshPmqqko.To cite this article: Oane Visser, Max Spoor \& Natalia Mamonova (2014)

Is Russia the Emerging Global 'Breadbasket'? Re-cultivation, Agroholdings and Grain Production, Europe-Asia Studies, 66:10, 1589-1610

than 26 million hectares, an estimated 2 million hectares more than the top years 1992, 1993 and 1997 in the previous decade. The yields improved from 1.5 tons/ha during the period 1990-2000 to 1.9 tons/ha in the period 2002-2012 (RosStat 2013a), which is substantial but still much lower than Russia’s competitors, such as Canada and the US.

In conclusion, there is a gradual improvement in grain output, due to a small increase in acreage, and a bit larger increase in yields, which is translated, in spite of strong fluctuations (caused by recurrent droughts) in increased exports of wheat to world markets (Figures 1 and 3).

\section{Russia's re-cultivation potential for wheat}

The image of Russia's emergence as the global breadbasket is based on the idea of growing wheat production, but it was shown in the previous section, the increase in production to date has been rather moderate. Further growth of Russia's grain sector strongly hinges on the potential of re-cultivating abandoned agricultural land for wheat production.

However, several factors might hinder re-cultivation of such 'reserve land'. First, of all there are often high initial costs for clearing the land and making it suitable for cultivation, as land may have been abandoned for over 10 to 15 years, and overgrown with shrubs and bushes. While this factor is frequently mentioned (see e.g. Liefert et al. 2013, p. 7; USDA 2010), there are more hindrances.

What can be observed clearly is that the reported dramatic downfall in cultivated areas in Russia was not in the production of wheat, which grew in the 2000s with about 2 million hectares. As share in the total sown area with all agricultural crops wheat increased from 21.2 percent in 1992 to 34.6 percent of a substantial shrunk total area in 2008 (USDA 2010). The decline in cultivated areas has actually taken place in coarse grain, in part because these are more closely related with the animal husbandry sector, which collapsed in the early 1990s (see Table 2).

\section{[Table 2]}

Actually, a large share of the cultivated land, namely around 25.0 million hectares which was taken out of production, was previously dedicated to the production of coarse grains, such as rye, barley, oats (which all three dropped dramatically) and corn (that increased somewhat). Therefore, this is not land that used to be planted with wheat, and it is questionable whether this large "available" acreage will be possible to be converted into wheat lands, such as is suggested by Schierhorn et al. (2012), who note that in the European part of Russia there is 26 million hectares of land that can be re-cultivated. The Russian government has propagated the idea to bring unused land into use for grain production. However as evidenced by a statement by the then president, Medvedev in early 2010, the focus is specifically on feed grain for livestock, instead of wheat. ${ }^{5}$

Further, a study by Prishchepov et al. (2013) focusing on European Russia shows that grain land abandoned in the 1990s, was farmland where yields in the 1980s were below average, and with higher distances from the nearest settlements. Low grain yields largely explained why these lands were abandoned. This provides further evidence suggesting that re-cultivating much of the abandoned land for wheat production (and sometimes even for other coarse grains) would not be profitable, and is therefore unlikely to happen.

\footnotetext{
5 Sel'skaya zhizn’ February 4-1- 2010, p.2 cited in Wegren 2011: 152.
} 
The importance of agroholdings in the various regions gives an indication of the extent to which outside capital is going into the areas with abandoned land. Estimations based on research by IKAR (Rylko 2011) show that the share of agroholdings in regional arable land, is the highest in the fertile Central Black Earth region (45 percent), and the South (21 percent) with Russia’s prime soils and climate. Going further East the percentage of agroholdings goes down from 17 percent in the Volga region, 9 percent in the South-Ural, to 7 percent in Western-Siberia. ${ }^{6}$

Furthermore, if we look specifically at grain, the regional location of the top-100 largest grain producers presents an even more pronounced geographical distribution (VIAPI 2009, pp. 55-62). From an analysis of the top-100 grain producers data it appears that the top grain producers hardly venture into the more marginal areas with the vast stretches of abandoned land. Of all these 88 are located in the South and the Central Black Earth with the prime soils and climatic conditions. Even in the regions East of the Volga, where soils are excellent and high yields can be achieved in good years, but excessive droughts can also occur, hardly any of the largest agricultural producers are present. Only two of the top-100 producers were located in the Volga region, two in Tatarstan and four in Siberia. ${ }^{7}$ In WestSiberia, which is in principle also a major wheat producing, the increase production is primarily constrained by inhibiting long distances to ports, and low local demand (USDA 2010).

It is also questionable whether the abandoned land can be converted into cultivated land without producing large greenhouse gas (GHG) emissions, as they have become large carbon sinks after more than 10-15 years of having left fallow (Kurganova et al. 2007). A detailed study by Meyfroidt et al. (2012) confirms these risks, and concludes that only 8.7-8.9 million hectare can be re-cultivated "with relatively lower environmental costs". ${ }^{8}$ They estimated that in Russia (including the Asian part) 43.5 million hectares was abandoned. Their analysis underscores our argument that much of the "available" land in Russia will not be recultivated in the near future without substantial costs, and even are not likely to produce high yields (especially North-European Russia), and/or profitably market and export produce (especially in Western-Siberia).

\section{Land Reform: large-scale farming continued}

\footnotetext{
${ }^{6}$ Within the Central Black Earth large differences exist in terms of the share of agroholdings in total arable land, which are more dependent of the agricultural policies of the various oblasts (regions). Belgorod region which has strongly supported agroholding development is estimated to have the highest share (85 percent) of agricultural land controlled by agroholdings, followed by Lipetsk (75 percent), Kursk (50 percent) whereas in Voronezh this figure is 25 percent (Rylko 2011). In Orel, another region which is known for its active stimulation of, agroholdings accounted for at least 41 percent of agricultural land in 2008 (Grouiez 2012). In Belgorod 73 percent of agricultural land was controlled by agroholdings before 2005 according to Petrikov (2005) and Hockmann, Bokusheva \& Bezlepkina (2007). In 200182 percent of arable land was controlled by agroholdings according to Hahlbrock and Hockmann (2011b, p. 3). According to these authors this share had declined to 67 percent by 2007, but they do not provide an explanation why such a reversal of the trend would have happened, and this decline does not correspond with the estimation of Rylko (2011) that 85 percent of the arable land is controlled by agroholdings. Nevertheless, it is clear that the share of agroholdings in land in Belgorod is very high, and among the highest, if not the highest, in Russia.

7 The 2 enterprises east of the Volga are located in Penza and Saratov, and in Siberia; 1 in Omsk and 1 in Novosibirsk, 2 in Krasnoyarsk. Also 2 are located in Tatarstan, which is quite an atypical region, due to heavy state subsidies into agroholdings based on the regional oil industry. The 2 enterprises near Moscow, which are also the only ones in Europe’s non-black earth area, are located in Ryazan and Nizhnii Novgorod.

${ }^{8}$ This was stated during a presentation at the IAMO 2012 Forum in Halle, 20-22 June.
} 
This is an Accepted Manuscript of an article published by Taylor \& Francis in Europe-Asia Studies on 11 Nov 2014, available online:

http://www.tandfonline.com/doi/abs/10.1080/09668136.2014.967569\#.VeCshPmqqko.To cite this article: Oane Visser, Max Spoor \& Natalia Mamonova (2014)

Is Russia the Emerging Global 'Breadbasket'? Re-cultivation, Agroholdings and Grain Production, Europe-Asia Studies, 66:10, 1589-1610

In undertaking land reform and farm restructuring in the early 1990s the Yeltsin government chose for a "share-based" land distribution, which was also followed in countries such as Kazakhstan and Ukraine (as opposed to a "plot-based" land distribution, used elsewhere in Central and Eastern Europe). ${ }^{9}$ Individual farms that were formed in the early 1990s had some policy support, but the deficient and sometimes non-existing factor markets made it very hard for them to subsist or accumulate (Spoor \& Visser 2001, 2004; and Visser et al. 2012; Wegren 2008).

\section{[Table 2]}

Weakly defined user-rights (of the shares) and the overall crisis of the post-Soviet Russian economy made it possible for inventive entrepreneurs, former sovkhoz or kolkhoz chairmen, other members of the rural nomenklatura, but also criminal elements to gather large numbers of shares. In the early stages several forms of new enterprises were formed in that way (Wegren 2009), such as joint-stock companies, cooperatives and "peasant associations", although sometimes only changing the name plate. In Table 2 it is shown that since the early 1990s until 2011 there has been hardly any increase in the total number of household plots, but their average acreage has more than doubled, with the total land area growing from 3.2 million hectare in 1992 to 7.6 million hectare in 2011 (for a detailed study on household plots in Russia see Pallot and Nefedova 2007).

The number of peasant (or individual) farms grew rapidly in the 1990s to (at least according to the official data, as the real number might well be 25 percent less) a maximum of 278,600 in the year 1996 (occupying 12.4 million hectare), gradually decreasing to 260,500 in 2011 (with a slight increase total land acreage to 16.6 million hectares). ${ }^{10}$

The data in Table 2 show that land reform in Russia has not been as re-distributive, as was possibly intended in the early stages of transition. Indeed, a peasant (or individual) farm sector has emerged, but it has remained relatively small. The sector occupied 11.5 percent of agricultural land in 2011; if compared with the first transition year 1992 the peasant farm sector was still practically non-existent. The household sector (subsidiary plots and dacha gardens) increased its share from 1.6 to 5.3 percent of total agricultural land. Finally, while in 1992 the sovkhoz and kolkhoz farms had occupied 98.4 percent of agricultural land, their corporate heirs in 2011 still held an estimated respectable 83.2 percent. ${ }^{11}$

\section{Who produces grain in Russia?}

\footnotetext{
${ }^{9}$ Ukraine changed its policy in 1999 by transferring land shares into physical plots. However, it also installed a moratorium on sales, which was still in force in 2012 (Lerman \& Sedik 2007).

10 According to RosStat, around 60,000 of these peasant farms only existed on paper or they were hardly functioning (The Federal Target Programme № 172 of March 16, 2012 of The Ministry of Agriculture of The Russian Federation). If that figure is indeed true, our later calculations on land productivity should be adjusted upwards, as this is calculated by dividing output (which is really reported) by acreage (which might include a substantial amount of land of the 'paper tiger' category).

11 This seems more than has been reported in other sources, but it could be that the 13.9 million hectare reported by Serova (2010) as the category "other" should be included, lowering the share in agricultural land of agricultural companies to 76.3 percent. Our estimates are confirmed by a recent EBRD/FAO study, which stated: 'In the Russian Federation in 2010, 80 per cent of farmland was controlled by large corporations' (Rutten, 2012, p. 22).
} 
This is an Accepted Manuscript of an article published by Taylor \& Francis in Europe-Asia Studies on 11 Nov 2014, available online:

http://www.tandfonline.com/doi/abs/10.1080/09668136.2014.967569\#.VeCshPmqqko.To cite this article: Oane Visser, Max Spoor \& Natalia Mamonova (2014)

Is Russia the Emerging Global 'Breadbasket'? Re-cultivation, Agroholdings and Grain Production, Europe-Asia Studies, 66:10, 1589-1610

\section{Agricultural companies versus (peasant) farmers}

In order to understand developments in the grain sector in more detail, we asked ourselves who have actually produced wheat in Russia over the past two decades? In Table 3 we can see its development. Household plots are (not surprisingly) hardly used for wheat production, and therefore the contribution of this sector is practically negligible. However the contribution of farmers (fermery), peasant farmers (krestyansko fermerskie khozyaistva) and individual entrepreneurs (individualniye predprinimateli) has rapidly grown and was afterwards nearly constant at a level between 22-23 percent in the years 2009-2011.

\section{[Table 3]}

Yield differences between peasant farms and agricultural companies are relatively small, as can be shown in Figure 2, which depicts the annual development of wheat yields during the period 1990-2011. While most of the fluctuations in average wheat yields can be explained by weather conditions, it also seems that peasant farms have slightly closed the yield gap between their category of farms and agricultural companies (Figure 2).

[Figure 2]

\section{Agroholdings: land concentration and growing importance in grain}

Within the category of agricultural companies (or 'large farm enterprises') a concentration of land and capital took place. ${ }^{12}$ This phenomenon, however, is difficult to measure precisely.

Figures on the average size of agricultural companies do not show an increase (and actually show an initial decline). The size declined from nearly 7,500 in the 1990 s to 5,400 hectares in 2010 (see Table 3), as the number of large farm enterprises increased from an estimated 25,800 kolkhozy and sovkhozy in 1990, to 27,600 corporate large farm enterprises (LFEs) in the year 2000 (see Table 3). During the farm privatisation of the 1990s in some regions, such as Nizhnii Novgorod and Ryazan active downsizing of farm enterprises was promoted, in other cases the creation of peasant farms led to a decline in farm size.

Since the early/mid 2000s a process of (re)concentration is taking place, which is not so much visible in farm size figures of the LFEs, as in the 2000s their average size remained roughly stable (see Table 3). This apparent 'stability' of farm size, seems to be the outcome of two diverging trends related to the process of (re)concentration of land. Whereas weak LFEs show a decline in their acreage, strong ones expand (Visser 2008; Nikulin 2011). ${ }^{13}$ These authors describe cases of strong LFEs which expand by buying up (part of) the fertile land from nearby ailing ones. Another mechanism for expansion by the former is to rent or buy farmland from local authorities. Much of the less fertile land of ailing LFEs has also gone out of production. Pallot and Nefedova (2007: 83) state that loss-making large farms divested themselves of their least productive hectares by passing them onto district reserve land funds. Much of such reserve land, formally available for private farms or for rent, has been abandoned for lack of demand (ibid).

\footnotetext{
12 For studies analysing the drivers of this concentration see for instance Rylko (2010, 2011) and Visser, Mamonova and Spoor (2012).

${ }^{13}$ For a study on the diverging trends in weak and strong LFEs based on cases studies see Lindner (2008).
} 
This is an Accepted Manuscript of an article published by Taylor \& Francis in Europe-Asia Studies on 11 Nov 2014, available online:

http://www.tandfonline.com/doi/abs/10.1080/09668136.2014.967569\#.VeCshPmqqko.To cite this article: Oane Visser, Max Spoor \& Natalia Mamonova (2014)

Is Russia the Emerging Global 'Breadbasket'? Re-cultivation, Agroholdings and Grain Production, Europe-Asia Studies, 66:10, 1589-1610

Table 3 shows a decline in number of LFEs in the first decade of the 2000s, from 27,600 at the start of the decade to 22,500 in 2010, showing the effects of strengthened bankruptcy laws (e.g. in 1998) on the agricultural sector which had been non-solvent for a long time (Spoor \& Visser 2004). With the new Land Code (2003) being introduced, acquisition of (near) bankrupt LFEs and/or their landholdings was facilitated (Visser, Mamonova \& Spoor 2012).

Farm enlargement often takes the form of the formation of agroholdings, in which the size of the constituent farm enterprises may remain the same. As the Russian statistical bureau (e.g. RosStat 2013a) does not collect data on the level of agroholdings, we depend on estimations, which despite considerable variations, all show that the importance of agroholdings has grown in terms of their number and their share in acreage. ${ }^{14}$ The rapid increase continued till 2009, when the financial crisis hit Russia and constrained finances somewhat slowed down further expansion.

Indeed, the number of agroholdings (as well as the size of their land holdings) had rapidly increased since the early 2000s. According to the Russian Ministry of Agriculture in 2003, more than 90 agroholdings were active in 25 regions. By 2006, 319 corporate agroholdings were already registered (Uzun et al. 2009, p. 159).

There are no official statistics of the land areas farmed by agroholdings (as, again, reporting is for the individual farm enterprises and not for the total holding), but by mid-2008, according to an estimate of IKAR, 196 agroholdings controlled 11.5 million hectares of land (BEFL 2010, p. 9), while the total number of agroholdings was even over $300 .{ }^{15}$ According to some observers, by the mid-2000s in various fertile Black Earth regions, such as Belgorod, Lipetsk, Voronezh and Tambov there was practically no 'free' land available that was not yet controlled by an agroholding (Didenko 2009). ${ }^{16}$ Of the over 300 agroholdings in Russia, by 2007 there were 32 with landholdings of over 100,000 hectares (EBRD 2008, p. 7), while according to Rylko (2010) this was even more than 35. At least 12 major holdings controlled each 150,000 hectares or more, such as Cherkizovo, Nastyusha, Prodimex, Razgulay, SAHO, Yug Rusi and others (EBRD 2008, p. 7). In our own data search for the period 2009-2011 we found more than twenty of that size (see Table 4).

Agroholdings are generally seen as the motor of the recovery of the wheat sector. Estimations about the prospects of agroholdings are impressive, such as the prediction that they will account for 40-50 percent of the grain output by 2016 (EBRD 2008, p. 7), with possibly an even larger role in exports. ${ }^{17}$ However, our discussion of their current share in production and, later on, the problems in term of productivity, financial viability and management will question such optimistic predictions.

Indeed, when we take a closer look at the role of agroholdings, their production appears to be somewhat less impressive. According to Uzun et al (2012, p. 17) agroholdings accounted for 6.6 percent of the sown acreage for grain and 7.7 percent of the total grain

\footnotetext{
${ }^{14}$ Most of the land concentration and the corporatization of farm enterprises is undertaken by domestic capital, although there is also some foreign investment involved (Visser, Spoor \& Mamonova 2012; Visser \& Spoor 2012).

15 According to an earlier estimate by IKAR in Russia 350 agroholdings (including energy companies like Gazprom) farmed approximately 8 million hectares (EBRD 2008, p. 7).

${ }^{16}$ Although this statement seems a bit of an exaggeration, Rylko (2011) largely confirms this statement for some of these regions. In Belgorod agroholdings are estimated to control 85 percent of arable land (ibid).

${ }^{17}$ In comparison, in Kazakhstan agroholdings are estimated to control even 80 percent of total grain output (Rylko 2010).
} 
This is an Accepted Manuscript of an article published by Taylor \& Francis in Europe-Asia Studies on 11 Nov 2014, available online:

http://www.tandfonline.com/doi/abs/10.1080/09668136.2014.967569\#.VeCshPmqqko.To cite this article: Oane Visser, Max Spoor \& Natalia Mamonova (2014)

Is Russia the Emerging Global 'Breadbasket'? Re-cultivation, Agroholdings and Grain Production, Europe-Asia Studies, 66:10, 1589-1610

production (GAO) in 2006. It was recently estimated by the Institute for Agricultural Market Studies (IKAR) in Moscow that agroholdings account for 25 percent of grain output in Russia (Rylko 2010). Although this is a rough estimation (and more firm data on their recent share are lacking), most evidence (including the continued expansion of agroholdings in terms of number and acreage) indeed suggests a growing share of the agroholding during the first decade of the 2000s, although this growth may now have approached its limits.

\section{Agroholdings, productivity and efficiency}

Within the literature on agroholdings there is a strong focus on their emergence and expansion, and supposedly central role in driving modernization with productivity and profitability increases. They are seen as 'a progressive element' by 'bringing investment, superior technology, and better management practices' (Liefert et al 2013, p. 12). These authors state about agroholdings that:

These producers often introduce advanced technology through imports such as higher quality seeds, machinery, and animal breeding stock. They are especially interested in grain production because of the opportunities for profitable export. (..) their superior management and concern for cost-cutting and profitability would motivate them to use all inputs, including fertilizer, more efficiently.

While it is generally confirmed that agroholdings bring new technology such as Western machinery and new seeds (e.g. Hahlbrock \& Hockmann 2011a, Rylko 2010, 2011), the positive statements about productivity, superior management and profitability in agriculture in general, and the grain sector in particular, require a closer critical look. The available data for each of these indicators is limited, therefore we combine these separate indicators in order to achieve a more consistent picture.

\section{Productivity}

Looking at productivity, the rare empirical studies that were done on (agro)holdings in Russia give a mixed picture, but certainly do not reflect overall success. Guriev \& Rachinsky (2004) argue that the holdings of Russian oligarchs in general do not show a higher productivity than other enterprises, while their output growth is higher. Clarke (2004) states -based on extensive case studies in various enterprises- that innovation in these holdings is very limited. He speaks about holdings as largely a continuation of the Soviet firm. The few studies on the productivity (and efficiency) of agroholdings also do not support a merely positive evaluation. Hockmann, Bokusheva and Bezlepkina (2007), reporting on a study in Orel and Belgorod, showed that agroholdings are doing worse than independent farm enterprises. A later study in Belgorod by Hahlbrock and Hockmann (2011a) suggests that agroholdings do better on some accounts. ${ }^{18} \quad$ Looking at the (sparse) data on land productivity of grain specifically, it appears that despite more investment and technology in the agroholdings, and fertilizer use which was 260 percent higher than in other agricultural companies, grain yields were 'only 13 percent higher' than the latter (Uzun, Shagaida \& Saraikin 2012, pp. 28-29). ${ }^{19}$

\footnotetext{
18 They conclude: 'The result is twofold: on the one hand the conclusion can be verified that the technological and managerial innovations introduced by agroholdings do not necessarily increase the efficiency of agroholdings. On the other hand we could show that agroholdings are due to technical change the driving force of the shift of the production frontier'.

${ }^{19}$ It could be argued that agroholdings, who often took over bankrupt farm enterprises, started off from a lower level and need some more time to reach higher yields. Unfortunately, it is difficult to test this hypothesis. The
} 
Overall, countrywide the agroholdings contributed to an overall rise in Russia's total average yield that was 'insignificant' (ibid, p. 17). While the 324 grain producing enterprises which were part of agroholdings produced 2.1 tons per ha (higher than the 1.79 in independent agrocompanies), this pales in comparison with the yield of the top-100 of Russia's largest grain producers with 3.56 tons per hectare (VIAPI 2009).

\section{Profitability}

Looking at profitability, is should be noted that the literature on agroholdings with its strong focus on their emergence and expansion, is often characterised by a one-sided focus on the most successful ones and on aspects of agricultural modernization. There is hardly any attention for the many agroholdings which face financial difficulties, let alone on the ones which have failed, gone through a bankruptcy procedure and even disappeared from the sector.

Our first explorative web-search (see Table 4) on the financial state of agroholdings, gives quite a different picture than the one suggested for instance by the success stories on which the media focus, with titles such as 'Russian agriculture soon to kill of US agriculture' and 'Companies turn Collectives into profitable businesses' (Chazan 2001). Among the group of twenty five of the largest agroholdings in Russia (with each controlling at least 100,000 hectares of land) at least twelve have experienced severe financial problems, with some of them being forced to sell their assets and/or go through bankruptcy procedures (Table 4). Unfortunately, for some of the other agroholdings in this group no data about their financial situation was available.

\section{[Table 4]}

The case of Ivolga, the largest agroholding in Russia, is illustrative. This agroholding controls 700,000 hectares of land in Russia and 800,000 hectares in Kazakhstan. With its immense landholdings of in total 1.5 million hectares it is the largest crop producing agroholdings in the world. ${ }^{20}$ Like many of the largest Russian agroholdings it focuses predominantly at grain production. However, in the words of Angus Selby, an agricultural market analyst at a London Hedge Fund: 'They are the largest single entity in the world, but they have very low productivity' (Orange 2011). Ivolga currently experiences severe financial problems and is negotiating with Royal Bank of Scotland, which leads its creditors to restructure a US\$ 300 million loan it had received in 2007. Furthermore, it has offered its equity for sale as even the debt restructuring will be insufficient to keep this giant company afloat.

Among the 'smaller' agroholdings (which are not in the top 25) our research (focused on the brief period from 2009- mid 2012) also showed numerous cases of agroholdings that are highly indebted or are involved in the process of bankruptcy. Thus while there is a forefront of (apparently) successful and expanding agroholdings which are widely discussed in the media, there is also (a grossly overlooked) 'cemetery' of ailing and bankrupt ones,

more recent figures on the share of agroholdings in wheat are based on estimations, with the few studies comparing independent farm enterprises with those part of agroholdings do not focus on grain specifically.

${ }^{20}$ It leaves the Argentinia agroholding El Tejar, with its 1.2 million hectares at a considerable distance. For a study on the magnitude of agroholdings in the grain region of Kazakhstan see Petrick, Wandel and Karsten (2011). For an overview of agroholdings (especially those with foreign capital) in Ukraine, Kazakhstan and Russia see Visser \& Spoor (2011). 
This is an Accepted Manuscript of an article published by Taylor \& Francis in Europe-Asia Studies on 11 Nov 2014, available online:

http://www.tandfonline.com/doi/abs/10.1080/09668136.2014.967569\#.VeCshPmqqko.To cite this article: Oane Visser, Max Spoor \& Natalia Mamonova (2014)

Is Russia the Emerging Global 'Breadbasket'? Re-cultivation, Agroholdings and Grain Production, Europe-Asia Studies, 66:10, 1589-1610

which needs to be taken into account to make a balanced assessment of the emergence of sometimes huge agroholdings. ${ }^{21}$

The meagre score of the agroholding in terms of profitability is especially striking if we take into account not only that they bring in outside private capital, but also benefit from the strong state support for agroholdings (and megafarms) on federal and often regional level. Federal support for agriculture markedly increased since the early/mid-2000s, through a broad range of instruments (Wegren 2007a). ${ }^{22}$ From 2006 onwards, agriculture became a priority within the 'national project'. The government set ambitions goals for domestic food security, targeting first of all the livestock sector, which had experienced a dramatic fall in production during the 1990s. All those arrangements and in particular subsidies and subsidised loans tend to benefit mostly LFEs, and within this group in particular the agroholdings and megafarms. For instance, Uzun (2005) states that "1.4 percent of the largest corporate farms received 22.5 percent of all subsidies". Also, the more indirect forms of subsidisation seem to stimulate mostly the largest LFEs. ${ }^{23}$ Various requirements of the loans, such as the need for matching of resources and the short loan repayment period, tend to produce a bias in the loan portfolio in favour of LFEs and agroholdings.

In addition, favourable import restrictions (till Russia's WTO entrance in August 2012), stimulated large-scale agriculture. The 1990s were characterised by relatively free imports, guaranteeing cheap food for the urban population. However, by the mid-2000s when the oligarchs started to enter the agricultural sector, numerous changes in the import regulations took place which favoured domestic agriculture, and in particular the position of the agroholdings. For sugar, a flexible rate import tariff up to 270 USD per ton was announced. The import duty on rice increased from a 10 percent import duty to 120 USD per ton. Also, import tariffs on various dairy and meat products were markedly increased (Rylko 2010). It has been suggested that these import restrictions were influenced by the agroholdings, through aggressive lobbying (Hervé 2007). ${ }^{24}$

\section{Management}

While it is sometimes expected that agroholdings bring in 'superior management', the larger agricultural companies become, the more bureaucratic they also tend to be, more likely to incur large information, monitoring and governance costs (HLPE 2011, Spoor \& Robbins 2012, Williamson 1975). Hence, this should be taken into account in the studies on allocative and technical efficiency, and land productivity in the various farm enterprise types. Rylko (2010) of IKAR in Moscow, in a presentation about the importance of agroholdings in the grain market even jokingly suggested that they might have installed many post-Soviet departments, such as that of 'hoof-running monitoring', 'field-theft accounting' and 'strategic weather planning division', increasing monitoring and management costs. Clarke (2004) showed that post-Soviet management methods are prominent in the supposedly corporate

\footnotetext{
${ }^{21}$ The idea of a 'cemetery of agroholdings' was expressed by Alexander Nikulin in a discussion with one of the authors (Visser).

22 These included measures such as a debt restructuring programme, subsides crop insurance programmes, simplified and lowered taxes on agricultural and subsidies loans for capital investment (Wegren 2007a: 517).

${ }^{23}$ However, it should be noted that by the mid-2000s the national budget for the first time since the mid-1990s set aside a substantial amount of subsidies for household plots and private farms (Wegren 2007). This was policy was maintained in the 2010 Food Doctrine (Wegren 2011).

${ }^{24}$ It is relevant to note that the first branch of livestock production which the private agroholdings entered was the poultry sector. It seems to be no coincidence that the poultry market was also the first to benefit from import quota. When agroholdings started to enter other branches of the livestock sector, other import quota on livestock products (most notably pig farming) followed suit.
} 
capitalist enterprises. Steggerda and Visser (2012) indicated, based on an in-depth case study and interviews with farm managers and workers, how large farm enterprises and agroholdings with foreign involvement, against their initial ideas, deviate towards a more top-down Sovietstyle of management. Grazhdaninova \& Lerman (2004), in their study on allocative and technical efficiency of large corporate farms concluded that 'The low productivity of Russian agriculture is mainly attributable to management factors, and not to technological or allocative factors'. According to the governor of Belgorod only 8 out of 15 agroholdings in the region had fulfilled the expectation of technological and organisational innovations (Hockmann, Bokusheva \& Bezlepkina 2007). The failure of the other seven agroholdings was caused by lack of investment and/or weak management. Steggerda and Visser (2012) concluded that investment in new technology seldom leads to the expected rise in productivity, due to a wide range of problems in the sphere of management and labour relations impeding successful transfer of technology and knowhow. In line with these observations Rylko (2010) remarked: 'long-term technical and managerial efficiency of agroholdings is highly questionable'.

Taking into account the above-mentioned problems in terms of productivity, profitability and management, it is questionable whether the large-scale companies, and in particular the agroholdings, which have accumulated much land, will enable (further) growth in productivity and become the drivers of a new global 'bread basket' which is sometimes suggested. Indeed there is much land 'available' to be re-cultivated in Russia, which does not mean inhabited, or without 'owner' (Visser, Mamonova \& Spoor 2012),

If we would include social variables, such as employment and viability of rural communities, and take environmental sustainability into account, the risks and limitations of an 'agroholding path' of Russian agriculture become even more pronounced (e.g. Visser, Mamonova \& Spoor 2012). While some agroholdings do take social and environmental aspects seriously, the strive for quick expansion and profits by others has negative environmental and social effects (Nikulin 2005, Visser, Mamonova \& Spoor 2012). ${ }^{25}$

\section{From production to export: storage, demand for fodder, and price volatility}

Whether the growth in wheat production will translate in increased exports depends on domestic demand, especially the increased demand for fodder from the expanding livestock sector, and the development of export infrastructure.

For wheat and coarse grains, important crops for the agroholdings, we have shown that the sustained increase of grain production was much more limited than the impressive export figures during the years 2008 and 2009 actually suggest. Until the early 1990s a larger share of the grain production was used as animal feed. With the collapse of the animal husbandry sector, which has only slowly been recovering from the mid-2000s, albeit still at lower levels than during the Soviet era, more of domestic grain is used for human consumption (whether domestically or for export). ${ }^{26}$ However, with declining grain prices for human consumption due to domestic over-supply in bumper harvest years (stimulating agricultural producers to reduce grain production and/or shift to fodder grain), and growing demand for fodder due to growth of the (subsidised) livestock sector, the volume of wheat available for export in the coming years may not be so high as some predictions suggest.

\footnotetext{
25 Interview with A. Nikulin, Russkiy Reporter (Russian Reporter), 14, 243, 11/04/2012, available at http://rusrep.ru, accessed 20 April 2012.

${ }^{26}$ The number of pigs for instance increase after the lowest headcount since the 1950s (13.7 million in 2004) to 17.2 million in 2010 (Rosstat 2011). Poultry production even more than doubled in the period 2004-2010 (Rylko 2011, p. 5).
} 
This is an Accepted Manuscript of an article published by Taylor \& Francis in Europe-Asia Studies on 11 Nov 2014, available online:

http://www.tandfonline.com/doi/abs/10.1080/09668136.2014.967569\#.VeCshPmqqko.To cite this article: Oane Visser, Max Spoor \& Natalia Mamonova (2014)

Is Russia the Emerging Global 'Breadbasket'? Re-cultivation, Agroholdings and Grain Production, Europe-Asia Studies, 66:10, 1589-1610

Furthermore, the weak infrastructure in Russia (a legacy from the Soviet period when Russia did not export much grain, and was a grain importer) hinders export of grain. For a rise in grain production to translate in increased exports, it is crucial that the currently weak infrastructure (storage, rail and ports) will rapidly be developed. We will take a look here at storage as a key aspect of infrastructure in the grain chain.

Although grain export rose, the number of grain elevators did not increase until very recently. According to some sources the number of elevators remained unchanged throughout the first decade of the 2000s namely at 1147 elevators. According to others grain storage capacity even declined by over 10 percent from 108.2 million tons in 2008 to 97 million tons in $2009 .{ }^{27}$

The lack of storage capacity exaggerates the price volatility caused by the earlier mentioned strong annual volatility in harvested amounts, which might contribute to global price volatility. The comparison of Russian and World wheat production and export shows that there is no indication that Russia's increase production and export, mitigate volatility in produce and exports (see Figure 3). There seems to be more of a tendency that Russia's peaks and lows coincide more or less with World trends, although a longer series of wheat export data would be needed to make more firm statements about the convergence of Russian and global trends.

By the end of the first decade of the 2000s the Russian government took several measures to stimulate the expansion of infrastructure for grain export. In 2009, the United Grain Company was created in order to stimulate investments in grain infrastructure in order to enhance exports (USDA 2010). Moreover, in the same year the Russian government extended its interest rate subsidies to loans for construction of elevators (ibid).

However, with the shifting focus of agrarian policy towards the livestock sector, and the more constrained finances after the global financial crisis hit Russia, it is likely that such support to the export-oriented part of the grain sector is not further expanded or even curbed. The state support for agriculture goes now predominantly to the livestock sector, in accordance with the Food Security Doctrine of 2010, while federal support for the crop sector is 'not significant' (USDA 2010). Indicative is that the largest investor in grain elevators is now Cherkizovo (Rylko 2010), the largest livestock agroholding in Russia, which in the past few years is expanding its own fodder grains production. The 2012 WTO accession means a phasing out of high import tariffs for livestock. As a result in the short-run animal husbandry is expected to suffer dislocations (Wegren 2007b). However, the Russian government will likely try to continue its support for the livestock sector as much as possible (Wegren 2011), in line with its food security doctrine.

\section{Conclusions}

In this article we critically investigated four assumptions that underlie the expectation that Russia would become a global breadbasket.

Firstly, the implicit assumption that the strong rise of wheat exports (although with high annual fluctuations) directly reflects a more or less equally drastic increase in production. In this paper we have confirmed, but also substantially qualified the observation that Russia has "recovered" as a grain producer. Indeed, wheat production has grown to higher levels, as the trough years in the second decade of transition are actually close to the

27 Khraneniye i Pererabotka ZERNA Scientific-Practical Journal. Available from: http://hipzmag.com/index.php?option=com_k2\&view=item\&id=187:187\&Itemid=15, accessed 13 August 2012. 
peak years in the first decade. However, there are still substantial fluctuations in total output, primarily caused by differing weather conditions. ${ }^{28}$ Imports have dropped to negligible levels, and in the top years 2009 and 2011 exports went up to nearly 16 million tons of wheat, transforming Russia during the good harvest years into the third (2009) or fourth (2011) global exporter of wheat. At the same time, the wheat acreage remained rather constant (2224 million hectares) although in 2008-2009 there was an additional 2 million hectares harvested, compared with previous years. The growth in export has for a large part been caused by the decreased demand for grain by the drastic slump in livestock production in the 1990s and early 2000s. Also much of the Russian wheat is of low quality, producers can rather easily shift between consumption and feed wheat.

Secondly, this study shows that the assumption that Russia's large 'land reserves' can and will be used for an increase in wheat production is problematic. Around 40 million hectares of arable land, mostly planted with cereals and leguminous crops were taken out of production in the 1990s, particularly affecting the production of coarse grains. There is no "recovery" in that part of Russian grain production as yet, as the production acreage of coarse grains dropped from 35 million in 1992 to around 10 million hectares in 2010, and production of mainly rye, barley and oats fell from 57 million tons to 17 million tons during the same period. This is mostly due to the severe crisis that occurred in the livestock sector during the 1990s with consequently much lower demand, which -with economic growth, and increased incomes- slightly recovered during the second half of the 2000s.

We have looked at the large area of abandoned land in Russian, which is more than 40 million hectares, of which at least 25 million hectares have previously been cultivated by coarse grains. Re-cultivation of this available land reserve will however be not as easy as it looks. Private investors and farmers will have to take substantial risks in a sector in which prices are volatile and in the past few years rather low, and infrastructural, logistic and marketing problems are still substantial. Furthermore, a rapid expansion of wheat production (in order to ease the tense global food market) is also not to be expected as soils are not always suitable, water shortages are important, and the environmental costs of re-cultivation in terms of a negative balance in carbon-sequestration are high. In sum, the press reports (sometimes supported by academic studies) that Russia has still lots of 'virgin lands' to be cultivated with wheat are clearly too optimistic.

Thirdly, we investigated the common idea that the expansion of agroholdings is a sign of their efficiency, and therefore these companies will drive a further growth in productivity and efficiency in agriculture, and the wheat sector in particular. Although the data is yet limited, our investigation of productivity, profitability and management in these enterprises clearly questions the optimistic predictions about the role of agroholdings in further raising wheat production. The evidence on the productivity of agroholdings compared with other producers is rather mixed, and certainly does not provide firm indication of a major advantage over other enterprises. If we look at the development of land productivity for wheat, and compare the peasant farm sector and the sector of agricultural companies (not differentiated between LFEs and agroholdings), we see that the "yield gap" between the two sectors is relatively small. We showed that the peasant farms have even been able to catch up somewhat, in spite of all the obstacles they face, and the virtual absence of supportive policies towards them (Pallot \& Nefedova 2007, Visser, Mamonova \& Spoor 2012).

\footnotetext{
${ }^{28}$ It is interesting that there is now growing recognition that weather conditions are very much influencing Russian grain output. During the Soviet era, these fluctuations were seen by western observers as an outcome of the inefficiencies of the production system, and excuses about weather conditions by Soviet authorities were easily dismissed.
} 
The idea that agroholdings will generate widespread innovation and increases in productivity in the coming years is questionable when one takes into account the evidence about management problems we briefly discussed. Furthermore, innovation may be hampered by financial problems and bankruptcies among agroholdings (as well as social and environmental problems). Our investigation of the financial state of the 25 largest agroholdings shows that in spite of their generally "good press", half of them were in financial difficulties, or in a procedure of bankruptcy. This is especially striking when one takes into account the generous state support to agriculture (and, until 2012, import tariffs), from which particularly the agroholdings have profited. Widespread innovations in the wheat sector are particularly doubtful, as wheat prices and margins have become lower (USDA 2010), and due to this and the volatile prices, there seems to be a recent tendency of agroholdings to move away from grain mono-cropping towards more diversified production (ibid). Moreover, subsidies for the livestock sector, even if decreasing with WTO membership, might reinforce a shift in attention of agroholdings from wheat towards livestock and feed grains. ${ }^{29}$

Fourthly, this study shows that even if wheat production would increase markedly this would not automatically turn Russia into the prime wheat exporter. For that to happen the infrastructure in terms of storage, transport and port, would have to improve greatly. Although, investment in this sphere has recently increased, this may be hampered by the shift of the government away from promoting Russia as a global grain powerhouse (with ambitions of establishing a grain OPEC), towards the ambition of increased food security (or more correctly self-sufficiency).

In conclusion, our findings suggest that Russia is not likely to surpass the US and become the World's number one wheat exporter in this decade. ${ }^{30}$ Furthermore, as Russia's wheat production is extremely volatile it might contribute to global price volatility, rather than contributing positively to global food security.

\footnotetext{
${ }^{29}$ Part of the farm enterprises might also shift to for instance oilseeds, legumes or perennial grass (USDA 2010). Furthermore, we agree with Wegren (2011) that it is likely that the Russian government will continue support for livestock as much as possible.

${ }^{30}$ If this would happen, it is likely to be caused to a large extent by a reduction of grain export by the US (due to the subsidised shift to biofuels), and only partly due to Russia's increase in wheat exports.
} 


\section{References}

Altukhov, A.I. (2011), 'Infrastructural support of grain market in Russia. Problems and solutions'. Available at: http://hipzmag.com/index.php?option=com_k2\&view=item \&id=187: 187\&Itemid=15, accessed 19 August 2012.

BEFL (2010) 'Russian market of agricultural land', presentation by BEFL director Vladislav Novoselov at the international conference for agricultural producers and suppliers of agricultural inputs and services, Radisson SAS Slavyanskaya hotel, Moscow, January 26. Available from: www.befl.ru/upload/iblock/929/ 929f8158fc6ad860217670c54c 42b873.pdf accessed 22 July 2013.

Bloomberg (2013). Russia's Wheat Exports Seen by SovEcon Declining Next Season. Available from: http://www.bloomberg.com/news/2013-03-01/russia-s-wheat-exportsseen-by-sovecon-declining-next-season.html accessed 3 Aug 2013.

Amanor, K. S. (2012), 'Global resource grabs, agribusiness concentration and the smallholder: two West African case studies', Journal of Peasant Studies, 39, 3-4.

Berezhnaya, A. E. (2004), Razmeri agropredpriyatiy i effectivnost' proizvodstva [The size and efficiency of agroenterprises] in Berezhnaya A.E. (eds.) Ekonomika sel'skokhozyaistvennykh i pererabatyvayushchikh predpriyatii [Economy of agricultural and processing enterprises] (Stavropol: SevKavGTI).

Boldyrev, F. (2001), 'Roga i kopyta. Pochemu oligarkhi zainteresovalis' sel'skim khozyaistvom' [Horns and hooves. Why oligarchs became interested in agriculture]. Kompaniya, 188, 42.

Borras, S.M. Jr. (2007), Pro-poor Land Reform: A Critique (Ottowa, University of Ottawa Press).

Borras, S.M. Jr., J. C. Franco, S. Gómez, C. Kay \& M. Spoor (2012), 'Land grabbing in Latin America and the Caribbean', Journal of Peasant Studies, 39, 3-4.

Bush, J. (2008), 'Farming makes a comeback in Russia', Business Week, 9 October. Available from: www.farmlandgrab.org/2537, Accessed 20 September 2010.

Chazan, Guy (2001), 'Companies turn Collectives into profitable businesses', Wall Street Journal, February 15.

Clarke, S. (2004), 'Very Soviet Form of Capitalism? The Management of Holding Companies in Russia’, Post-Communist Economies, 16, 4.

De Schutter, O. (2012), 'A Tale of Four Hungers', in: M. Spoor and M.J. Robbins (eds), Agriculture, Food Security and Inclusive Growth (The Hague: SID, NCDO and ISS).

Deininger, K. and D. Byerlee (2011), 'The Rise of Large-Scale Farms in Land-Abundant Developing Countries: Do They Have A Future?, Policy Research Working Paper 5588, Development Research Group, Agriculture and Rural Development Team (Washington DC, The World Bank).

Didenko, L. (2009), 'Pyat' gektarov - I korova', [Five hectares and a cow], Kommersant Guide, 16, 1.

EBRD/FAO (2008), Fighting food inflation through sustainable investment (London, EBRD).

EDB (2010), Integration Yearbook 2010 (Almaty, Eurasian Development Bank). 
This is an Accepted Manuscript of an article published by Taylor \& Francis in Europe-Asia Studies on 11 Nov 2014, available online:

http://www.tandfonline.com/doi/abs/10.1080/09668136.2014.967569\#.VeCshPmqqko.To cite this article: Oane Visser, Max Spoor \& Natalia Mamonova (2014)

Is Russia the Emerging Global 'Breadbasket'? Re-cultivation, Agroholdings and Grain Production, Europe-Asia Studies, 66:10, 1589-1610

FAOSTAT (2013a), The Agricultural Trade domain. Available at http://faostat3.fao.org/home/index.html\#DOWNLOAD, Accessed: 1 Aug 2013.

FAOSTAT (2013b), The Agricultural Production domain. Available at: http://faostat3.fao.org/home/index.html\#DOWNLOAD, Accessed: 1 Aug 2013.

GAIA (2008), 'Financing agriculture: Impact of the financial crisis', presentation at the UNIDO agriculture conference 'from farms to markets' (Cairo, GAIA Capital Advisors), November.

Grazhdaninova, M. \& Z. Lerman (2004), 'Allocative and Technical Efficiency of Corporate Farms in Russia', Discussion Paper 12.04, The Centre for Agricultural Economic Research, Department of Agricultural Economics and Management (Jerusalem, The Hebrew University).

Grouiez, Pascal (2012) 'Farming Strategies regarding the Production of Collective Goods in the Russian Agricultural Sector'. LEMNA working paper EA 4272, Nantes: University of Nantes. Available from: http://halshs.archives-ouvertes.fr/docs/00/69/43/52/PDF /LEMNA_WP_201220.pdf accessed 31 July 2013.

Guriev, S. \& A. Rachinsky (2004), 'Russian Oligarchs: A Quantitative Assessment', Transition, 15, 1. Available at: www.worldbank.org/transition newsletter, Accessed 1 January 2010.

Hahlbrock, K. \& H. Hockmann (2011a), 'Does group affiliation increase productivity and efficiency in Russia's agriculture? Evidence from agroholdings in the Belgorod Oblast', Paper presented at the EAAE 2011 Conference 'Change for Agriculture, Food and Natural Resources' (Zurich, ETH).

Hahlbrock, K. \& H. Hockmann (2011b) 'Influence of the integration of agroholdings with Russian farms on total factor productivity and its subcomponents'. Paper presented the $51^{\text {st }}$ GEWISOLA Jahrestagung 'Unternehmerische Landwirtschaft zwischen marktanforderungen und gesellschaftlichen erwartungen’, 28-30 September , Halle.

Hockmann, H. R. Bokusheva and I. Bezlepkhina (2007) 'Agroholdings Membership: Does that Make a Difference in Performance?' Paper presented at the $102^{\text {nd }}$ EAAE conference 'Superlarge Farming Companies: Emergence and Possible Impacts', 16-17 May 2007, Moscow. Available from: http://purl.um.edu/10023 accessed 31 July 2013.

Hervé, J.J. (2007), Des kolkhozes à l’hypermarché (Paris, L’Harmattan).

HLPE (2011), Land tenure and international investments in agriculture, Report of the High Level Panel of Experts on Food Security and Nutrition, Report Nr. 2, Committee on World Food Security (Rome, Food and Agriculture Organization of the United Nations).

Hockmann, H., J. Wandel \& A. Nedoborovskyy (2005), 'Agroholdings in Russia: Breaking the Vicious Circle?', Paper presented at the $94^{\text {th }}$ EAAE Seminar, 'From households to firms with independent legal status: the spectrum of institutional units in the development of European agriculture', 9-10 April, Ashford, UK.

IKAR (Institute of Economic Research in Agricultural Market) (2013) 'Russian wheat exports will include a wider palette of countries’, http://ikar.ru/press/1613.html, accessed 26 July 2013.

Index Mundi (2013). ‘ Wheat Exports by Country' . Available: http://www.indexmundi.com/agriculture/?commodity=wheat\&graph=exports accessed 3 Aug 2013. 
This is an Accepted Manuscript of an article published by Taylor \& Francis in Europe-Asia Studies on 11 Nov 2014, available online:

http://www.tandfonline.com/doi/abs/10.1080/09668136.2014.967569\#.VeCshPmqqko.To cite this article: Oane Visser, Max Spoor \& Natalia Mamonova (2014)

Is Russia the Emerging Global 'Breadbasket'? Re-cultivation, Agroholdings and Grain Production, Europe-Asia Studies, 66:10, 1589-1610

Jouko N. \& L. Granberg (2011), 'The global food crisis and changes in the Russian agricultural regulation', Paper presented at the International Radboud University/ISS/MSSES conference: 'Land accumulation in the former Soviet Union and beyond: Global investors and local communities’, 27 October, (Moscow, MSSES).

Kalb, D. \& O. Visser (2012), 'Oligarchy and State Capture: Soviet-style Mechanisms in Contemporary Finance Capitalism’, in: J.G. Carrier (ed), A Handbook of Economic Anthropology, Second Edition (London, Edward Elgar).

Kalugina, Z. \& O. Fadeeva (2009), 'Rossiiskaya derevnya $v$ labirinte reform. Sotsiologicheskiezarisovki' [Russian village in the labyrinth of land reforms], (Novosibirsk, Institut Ekonomiki i Organizatsii Promyshlennogo Proizvodstva Sibirskogo otdeleniya RAN) (Moscow, Institute of Economics and Industrial Production Management of Sibirian department of Russian Academy of Science).

Kandell, J. (2009), 'Betting on the Russian Farm', Institutional investor in: http://farmlandgrab.org/post/view/13810, accessed 22 May 2012.

Kurganova, I. N., A. M. Yermolaev, V. O. Lopes de Gerenyu, A. A. Larionova, Ya. Kuzyakov, T. Keller \& S. Lange (2007), 'Carbon Balance in the Soils of Abandoned Lands in Moscow Region', Eurasian Soil Science, 40, 1.

Liefert, O., W. Liefert \& E. Luebehusen (2013) Rising Grain Exports by the Former Soviet Union Region. Causes and Outlook. USDA Outlook February 2013. www.ers.usda.gov/media/996699/whs13a01.pdf accessed 22 July 2013.

Lerman, Z. (2008), Russia's Agriculture in Transition: Factor Markets and Constraints to Growth (Lanham, Rowman \& Littelfield/Lexington Books).

Lerman, Z., C. Csaki \& G. Feder (2004), Agriculture in Transition: Land Policies and Evolving Farm Structures in Post-Soviet Countries (Lanham, Rowman \& Littelfield/Lexington Books).

Lerman, Z. \& D.J. Sedik (2007), 'Productivity and Efficiency of Corporate and Individual Farms in Ukraine'. Discussion Paper No. 14.07, presented at 2007 Annual Meeting of American Agricultural Economics Association (New Name 2008: Agricultural and Applied Economics Association), July 29-August 1 (Portland, Oregon TN).

Liefert, O., Liefert, W. and E. Luebenhusen (2013), ' Rising Grain Exports by Former Soveit Union Region: Causes and Outlook’ , USDA Report WHS-13A-01, Washington: United States Department of Agriculture.

Liefert, W. \& O. Liefert (2012), 'Russian Agriculture during Transition: Performance, Global Impact and Outlook', Applied Economic Perspectives and Policy, 34, 1.

Lindner, P. (2008) Der kolchoz-archipel im privatisierungsprozess: Wege und umwege der Russischen landwirtschaft in die globale marktgesellschaft. Bielefeld: University of Bielefeld.

Lipton, M. (2009), Land Reform in Developing Countries: Property Rights and Property Wrongs (London, Routledge).

Matyukha, A. \& J. Wandel (2009), 'Oligarchs: The founding fathers of Russian Agricultural Entrepreneurship’, Mimeo, Transition Issues, O57-2.

Meyfroidt, P., P. Hostert, T. Kuemmerle, E. F. Lambin, D. Müller, F. Schierhorn \& A. Prishchepov (2012), 'Potential additional cropland, socioeconomic and environmental 
This is an Accepted Manuscript of an article published by Taylor \& Francis in Europe-Asia Studies on 11 Nov 2014, available online:

http://www.tandfonline.com/doi/abs/10.1080/09668136.2014.967569\#.VeCshPmqqko.To cite this article: Oane Visser, Max Spoor \& Natalia Mamonova (2014)

Is Russia the Emerging Global 'Breadbasket'? Re-cultivation, Agroholdings and Grain Production, Europe-Asia Studies, 66:10, 1589-1610

constraints and tradeoffs in Eastern Europe and Former Soviet Union countries', paper presented at the IAMO 2012 Forum 'Land Use in Transition', 20-22 June.

McChesney, A. (2011), 'Don’t call it a collective farm. It’s much bigger', The Moscow Times, 2 December. Available at: http://www.themoscowtimes.com/business/article/ qa-dontcall-it-a-collective-farm-its-much-bigger/449072.html, accessed 27 May 2012.

McMichael, P. (2009), ‘A Food Regime Genealogy’, Journal of Peasant Studies, 36, 1.

McMichael, Philip (2012), 'The land grab and corporate food regime restructuring', Journal of Peasant Studies, 39, 3-4.

Nikulin, A. (2005) Noveichaya gigantomaniya, Politichesskii Zhurnal, vol. 63, no.12.

Nikulin, A. (2011) Oligarkhoz as successor of post-Kolkhoz. Vestnik RYDN, seria 'socioligicia', 2.

Orange, R. (2011), 'Ivolga puts world’s largest farm up for sale’, The Telegraph, 13 February.

Pallot, J. and T. Nefedova (2007) 'Russia's Unknown Agriculture. Household Production in Post-Socialist Rural Russia’. Oxford: Oxford University Press.

Petrick, M., J. Wandel \& K. Karsten (2011), 'Farm restructuring and Agricultural recovery in Kazakhstan's grain region: an update', Discussion paper 137, Leibnitz Institute of Agricultural Development in Central and Eastern Europe (Halle, IAMO).

Petrikov, A., (2005). 'Tendentsii razvitiya integrirovannykh agropromyshchlennykh formirovanii’, APK:Ekonomika i Upravlenie, 1.

Prishchepov, A. V., D. Müller, M. Dubinin, M. Baumann, V.C. Radeloff (2013) 'Determinants of agricultural land abandonment in post-Soviet European Russia', Land Use Policy, 30.

RosStat (2013a). Agriculture, Hunting and Forestry / Gross Harvest of Crops by Different Types of Agricultural Producers. Available at: http://www.gks.ru/wps/wcm/connect/rosstat_main/rosstat/ru/statistics/enterprise/economy I\#, Accessed 1 August 2013.

RosStat (2013b) Agriculture, Hunting and Forestry / Crop Yields. Available at: http://www.gks.ru/wps/wcm/connect/rosstat_main/rosstat/ru/statistics/enterprise/economy /\#, Accessed 1 August 2013.

Rutten, L. (2012), Innovative agricultural finance and risk management; Strengthening food production and trade in the transition region, London/Rome: EBRD/FAO.

Rylko, D. (2010), 'New agricultural operators (“agroholdings”) in Russia and Black Sea FSU: causes, current state, and future challenges'. Available at: http://www.agribenchmark.org/fileadmin/Dateiablage/B-Cash-Crop/Conferences/ 2010/Presentations/a2-_agroholdings_in_Russia_Rylko.pdf, accessed 24 July 2013.

Rylko, D (2011) 'Russian New Agricultural Operators (Agroholdings): Emergence, Performance, and Impact on the Domestic and World Agriculture and Agribusiness'. Available at: https://moel.uni-hohenheim.de/fileadmin /einrichtungen/moel/Downloads/Rylko_Russian_Agroholdings_Oct_2011.pdf, accessed 02 Aug 2013.

RT (2013) 'Sugar producers tops Russia’s largest landowners list', May 2013, www.rt.com/business/russia-largest-land-sugar--428/ accessed 22 July 2013. 
This is an Accepted Manuscript of an article published by Taylor \& Francis in Europe-Asia Studies on 11 Nov 2014, available online:

http://www.tandfonline.com/doi/abs/10.1080/09668136.2014.967569\#.VeCshPmqqko.To cite this article: Oane Visser, Max Spoor \& Natalia Mamonova (2014)

Is Russia the Emerging Global 'Breadbasket'? Re-cultivation, Agroholdings and Grain Production, Europe-Asia Studies, 66:10, 1589-1610

Schierhorn, F., D. Müller, A. V. Prishchepov \& A. Balmann (2012), 'Grain potentials on abandoned cropland in European Russia', paper presented at the Annual World Bank conference on land and poverty, 23-26 April (Washington DC, World Bank).

Serova, E. (2010), 'Agrarian Reform in the Russian Transition Period'. Available at: http://ru90.ru/old/index.php?option=com_content\&view=article\&id=1864, accessed 14 June 2012.

SNG StatKom (1994), Statistischeskii eshegodnik, Moscow.

SNG StatKom (1997), Statistischeskii eshegodnik, Moscow.

State (National) Report on the State and Land Use in the Russian Federation in 2011. Available at: https://rosreestr.ru/wps/portal/p/cc_ib_other_lines_activity/ cc_ib_condition_earths_Russia/cc_ib_texts_of_documents, accessed 1 August 2013.

Spoor, M. (2012), 'Agrarian Reform and Transition: What Can we learn from 'The East'?', Journal of Peasant Studies, 39, 1.

Spoor, M. \& M. J. Robbins (eds) (2012), Agriculture, Food Security and Inclusive Growth, The Hague: SID, NCDO and ISS.

Spoor, M. \& O. Visser (2001), 'The State of Agrarian Reform in the Former Soviet Union', Europe-Asia Studies, 53, 6.

Spoor, M. \& O. Visser (2004), 'Restructuring postponed? Large Russian Farm Enterprises "Coping with the Market”, Journal of Peasant Studies, 32, 2.

Starobin, P. \& C. Belton (2002), 'Russia’s new wealth’, Business Week, 5 August, available at: www.businessweek.com/print/magazine/content/02_31/b3794013.htm?chan 1/4mz, accessed 1 March 2012.

The Federal Target Programme 'Support of beginning farmers 2012-2014' № 172 of March 16, 2012 within the State programme 'Development of agriculture 2008-2012' of The Ministry of Agriculture of The Russian Federation. Available at: http://www.mcx.ru/, accessed 15 June 2012.

USDA (2010) Russian Wheat Exports Potential. GAIN report no. RS1028, Foreign agricultural service USDA. http:/gain.fas.usda.gov/Recent\%20GAIN \%20Publications/Russian\%20Wheat\%20Exports\%20Potential_Moscow_Russian\%20Fed eration_6-15-2010.pdf accessed 23 July 2013.

Uzun, V. (2005), 'Large and Small Business in Russian Agriculture: Adaptation to Market', Comparative Economic Studies, 47, 1.

Uzun, V., E. Gataulina, V. Saraikin, V. Bashmachnikov, O. Pavlushkina \& O. Rodionova (2009), 'Tendentsii razvitiya i mekhanizmy vzaimodeistviya kruphnogo i malogo biznesa $v$ agropromyshlennom komplekse' [Trends in the development and mechanisms of interactionlarge and small businesses in the agricultural sector]. (Moscow, VIAPI Press).

Uzun,V. Ya., N.I.Shagaida, V.A.Saraikin (2012) 'Agroholdingi Rossii i ikh rol' $v$ proizvodstve zerna'. Issledovaniya po politike perkhoda sel'skogo khozyaistva No. 20122. FAO Regional Bureau for Europe and Central Asia.

VIAPI (2009) 'Reitingi krupneishikh proizvoditelei sel'skokhozyaistvennoi prouktsii v Rossii (2006-2008 gg.)'. Moscow: Vserossiiskii institut agrarnykh problem i informatiki im. A.A. Nikonova. www.viapi.ru/files/Agro300_2008.pdf accessed 22 July 2013. 
Visser, O. 2006. Property, Labour Relations and Social Obligations in Russia's Privatised Farm Enterprises, in: K. von Benda-Beckman, F. von Benda-Beckman \& M. Wiber (eds), The Changing Properties of Property (London and New York: Berghahn).

Visser, O. (2008), Crucial connections. The Persistence of Large Farm Enterprises in Russia, PhD Thesis Dept. of Anthropology and Development Studies (Nijmegen: Radboud University Nijmegen).

Visser, O. \& D. Kalb (2010), 'Financialised Capitalism Soviet Style? Varieties of State Capture and Crisis', European Journal of Sociology, 51, 2.

Visser, O. N. Mamonova \& M. Spoor (2012), 'Oligarchs, Megafarms and Land Reserves: Understanding land grabbing in Russia’, Journal of Peasant Studies, 39, 3-4.

Visser, O. and M. Spoor (2011), 'Land Grabbing in post-Soviet Eurasia: the world's largest land reserves at stake', The Journal of Peasant Studies, 38, 2.

VLANT (2012) Russian wheat exports in 2011. Available from: www.vlantconsult.ru/information/board/261 accessed 3 August 2013.

Wandel, J. (2011), 'Business groups and competition in post-Soviet transition economies: the case of Russian "agroholdings"', Review of Austrian Economics, 24, 4.

Wandel, J., A. Pieniadz \& T. Glauben (2011), 'What is success and what is failure of transition? A critical review of two decades of agricultural reforms in the Europe and Central Asia region', Post-communist economies, 23, 2.

Wegren, S. K. (2007a), 'The State and agrarian reform in post-communist Russia', Journal of Peasant Studies, 34, 3.

Wegren, S. K. (2007b), 'Can Russian Agriculture Compete in the WTO?', NBR Special Report, 12.

Wegren, S. K. (2008), 'Land Reform in Russia: What Went Wrong?', Post-Soviet Affairs, 24, 2.

Wegren, S. K. (2009), Land Reform in Russia: Institutional Design and Behavioral Responses (New Haven: Yale University Press).

Wegren, S. K. (2011), 'Food Security and Russia’s 2010 Drought’, Eurasian Geography and Economics, 52, 1.

Williamson, O. (1975) 'Markets and Hierarchies'. New York: Free Press.

Winter, S. (2012), 'Pigs and Protection Money: German Farmers Seek their Fortunes in Russia’, Der Spiegel, 12 January. Available at:

www.farmlandgrab.org/post/view/19872, accessed 12 January 2012.

World Bank (2011), Rising Global Interest in Farmland: Can it yield sustainable and equitable benefits? by K. Deininger \& D. Byerlee (Washington DC, World Bank). 
This is an Accepted Manuscript of an article published by Taylor \& Francis in Europe-Asia Studies on 11 Nov 2014, available online:

http://www.tandfonline.com/doi/abs/10.1080/09668136.2014.967569\#.VeCshPmqqko.To cite this article: Oane Visser, Max Spoor \& Natalia Mamonova (2014)

Is Russia the Emerging Global 'Breadbasket'? Re-cultivation, Agroholdings and Grain Production, Europe-Asia Studies, 66:10, 1589-1610

TABLE 1

WhEAT PRODUCTION By COMPANIES, HouSEHOLDS AND PEASANT FARMS (1990-2012) (IN MILLION TONNES)

\begin{tabular}{lcrrrrrrrrrrrrr}
\hline & 1990 & 1992 & 1994 & 1996 & 1998 & 2000 & 2002 & 2004 & 2006 & 2008 & 2010 & 2011 & 2012 \\
\hline $\begin{array}{l}\text { Agricultural } \\
\text { companies }\end{array}$ & 49.6 & 45.2 & 30.0 & 32.7 & 24.7 & 31.1 & 43.5 & 36.9 & 35.4 & 49.7 & 31.8 & 42.9 & 28.9 \\
Peasant farms & 0.00 & 0.9 & 2.1 & 2.1 & 2.2 & 3.3 & 6.9 & 8.3 & 9.2 & 13.8 & 9.5 & 12.9 & 8.6 \\
Households & 0.01 & 0.1 & 0.1 & 0.1 & 0.1 & 0.1 & 0.2 & 0.2 & 0.3 & 0.3 & 0.2 & 0.4 & 0.2 \\
All categories & 49.6 & 46.2 & 32.1 & 34.8 & 27.0 & 34.5 & 50.6 & 45.4 & 44.9 & 63.8 & 41.5 & 56.2 & 37.7 \\
\hline
\end{tabular}

Source: RosStat (2013a). Agriculture, hunting and forestry. Gross harvest of crops by different types of agricultural producers.

\section{IS RUSSIA THE EMERGING GLOBAL 'BREADBASKET'?}

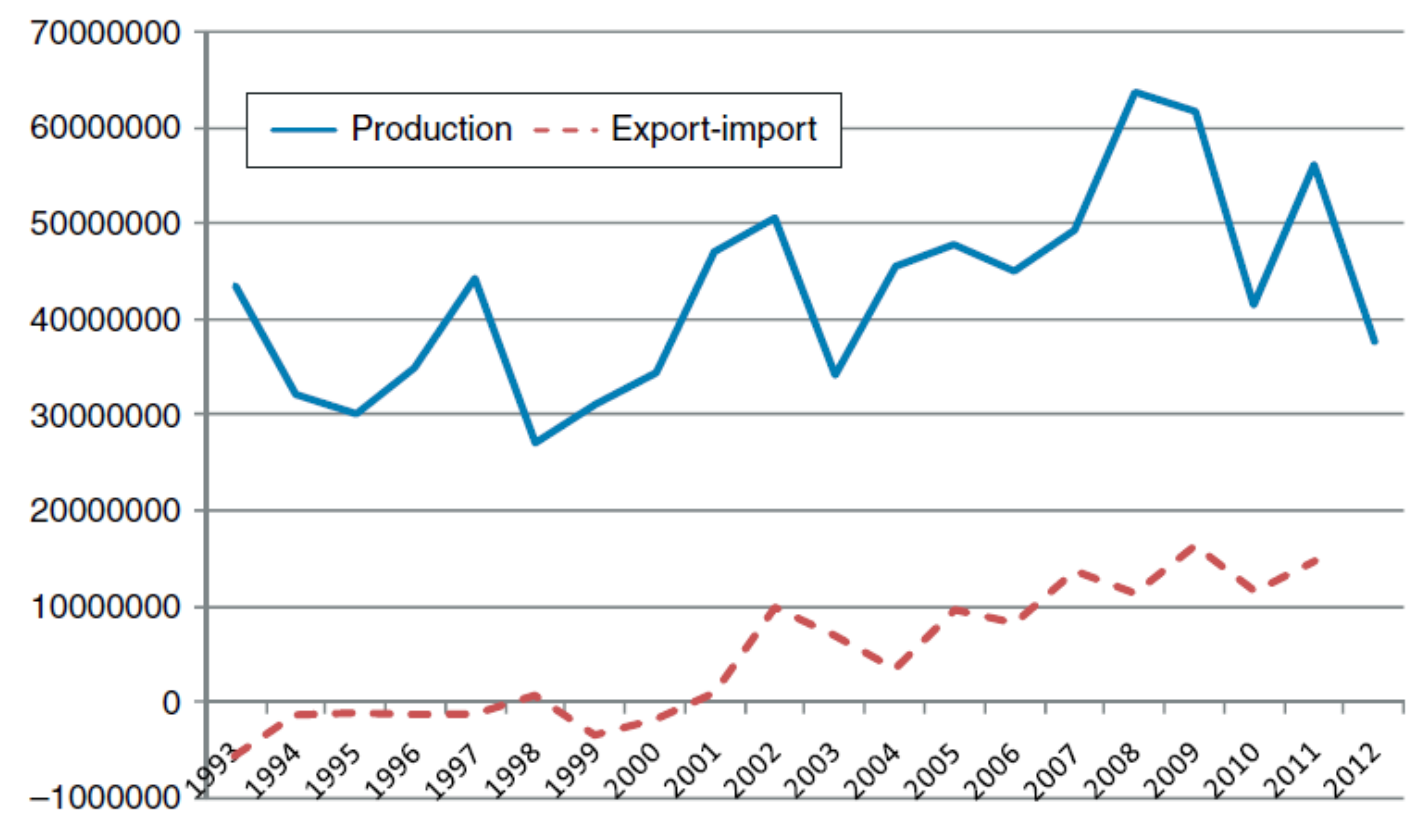

FIGURE 1. PRODUCTION AND EXPORT/IMPORT OF WHEAT (1993-2012).

Source: FAOSTAT (2013a, 2013b), composed based on the data from the FAOSTAT Agricultural Trade domain and Agricultural Production domain.

TABLE 2

CoArse Grain ACReage and Production (1992-2010)

\begin{tabular}{lrrrrr}
\hline & 1992 & 1996 & 2000 & 2005 & 2010 \\
\hline Harvested area (million hectares) & 35.0 & 25.9 & 19.6 & 17.3 & 10.5 \\
Production (million tons) & 56.9 & 32.3 & 29.3 & 28.3 & 17.1 \\
Yield (tons per hectare) & 1.6 & 1.2 & 1.5 & 1.7 & 1.6 \\
\hline
\end{tabular}

Source: FAOSTAT (2013b). (RosStat (2013a) provides similar, but not always the same data.) 


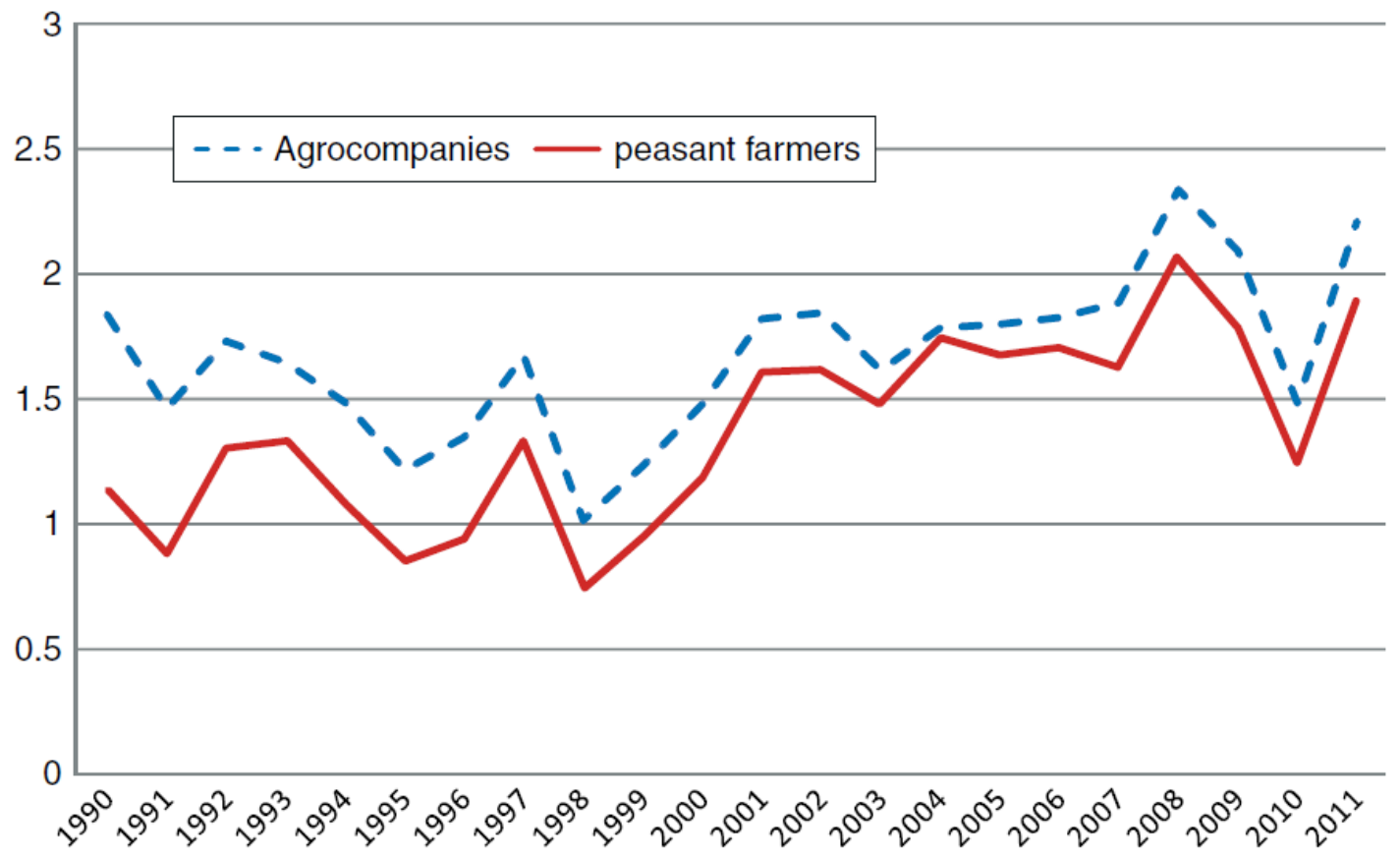

FIGURE 2. WHEAT YIELDS By DIFFERENT FARM CATEGORIES (1990-2011).

Note: It should be mentioned that the figures for peasant farmers for 1990 and 1991 are rather unreliable as their number was still extremely small.

Source: RosStat (2013b).

TABLE 3

Russian Land Reform and Farm Restructuring 1992-2011

\begin{tabular}{lcccccc}
\hline Agricultural land & 1992 & 1996 & 2000 & 2005 & 2010 & 2011 \\
\hline Peasant farms & & & & & & \\
$\quad$ Amount & 50 & 278,600 & 263,700 & 267,500 & 261,700 & 260,500 \\
$\quad$ Land (million hectares) & 0.002 & 12.4 & 15.4 & 14.9 & 16.3 & 16.6 \\
$\quad$ Average size of 1 unit (hectares) & 40 & 40 & 60 & 60 & 60 & 60 \\
Household plots & & & & & & \\
$\quad$ Amount (million) & 16.4 & 16.0 & 15.9 & 15.9 & 16.2 & 16.2 \\
Land (million hectares) & 3.2 & 5.7 & 6.2 & 7 & 7.5 & 7.6 \\
Average size of 1 unit (hectares) & 0.20 & 0.36 & 0.39 & 0.44 & 0.46 & 0.47 \\
Agricultural companies & & & & & & \\
$\quad$ Amount & 25,800 & $\mathrm{n} / \mathrm{a}$ & 27,600 & 25,300 & 22,500 & $\mathrm{n} / \mathrm{a}$ \\
$\quad$ Land (million hectares) & 193.2 & 174.8 & 149.7 & 130.8 & 121.3 & 120.1 \\
Average size of 1 unit (hectares) & 7,490 & $\mathrm{n} / \mathrm{a}$ & 5,420 & 5,170 & 5,390 & $\mathrm{n} / \mathrm{a}$ \\
\hline
\end{tabular}

Sources: For agricultural companies in 2005 the available data of 2006 are used, for 1996 those available for 1997 (SNG StatKom 1997). Most sources, such as SNG StatKom and RosStat, contradict each other on various accounts. For the second decade we used 'Gosudarstvennyi (Natsional'nyi) Doklad o Sostoyanii i Ispol'zovanii Zemel' v Rossiskoi Federatsii na 1 yanvarya 2011 goda’, available at: http://www.rosreestr.ru/cadastre/condition/documents/, accessed 28 August 2014. 
TABLE 4

FinANCIAL Difficulties AMONGST the LARGeSt AgROHOLDINGS in RUSSIA (2009-2011)

\begin{tabular}{|c|c|c|c|c|}
\hline Origin & $\begin{array}{l}\text { Landholdings } \\
\text { (hectares in } \\
\text { Russia) }\end{array}$ & Financial state & Agroholding & Outcome \\
\hline $\begin{array}{l}\text { Kazakhstan/ } \\
\text { Russia }\end{array}$ & $\begin{array}{c}700,000 \\
(+800,000 \text { in } \\
\text { Kazakhstan })\end{array}$ & $\begin{array}{l}\text { Financial difficulties; } \\
\text { defaulted on a US\$ } 300 \\
\text { million loan }\end{array}$ & Ivolga Holding & Shares for sale \\
\hline Russia & 570,000 & & GK Prodimex & \\
\hline Russia & 463,000 & Huge debts (2009) & Razgulai & \\
\hline Russia & 460,000 & & Napko & \\
\hline Russia & 450,000 & Huge debts (2011) & Zolotoi Kolos & $\begin{array}{l}\text { B ankruptcy procedure of } \\
\text { several enterprises of the } \\
\text { holding }\end{array}$ \\
\hline Russia & 420,000 & & Yug Rusi & \\
\hline Russia & 400,000 & Huge debts (2009) & VAMIN Tatarstan & Take over (?) \\
\hline Russia & 394,800 & $\begin{array}{l}\text { Huge losses and decrease } \\
\text { in production (2010) }\end{array}$ & $\begin{array}{l}\text { Krasny Vostok } \\
\text { Agro }\end{array}$ & Recovered \\
\hline Russia & 376,700 & Huge debts (2010) & $\begin{array}{l}\text { Sibirski Agrarnyi } \\
\text { Holding }\end{array}$ & $\begin{array}{l}\text { Has been paying its debt by } \\
\text { taking a credit of } \\
\text { Rosselkhozbank }\end{array}$ \\
\hline $\begin{array}{l}\text { Russia/ } \\
\text { Ukraine }\end{array}$ & 360,400 & & Valars Group & \\
\hline $\begin{array}{l}\text { Kazakhstan/ } \\
\text { Russia }\end{array}$ & 350,000 & Huge debts & Nastyusha & Bankruptcy procedures \\
\hline Sweden & 330,000 & Unprofitable & $\begin{array}{l}\text { Black Earth } \\
\text { Farming }\end{array}$ & $\begin{array}{l}\text { Major restructuring, small } \\
\text { profit in } 2012\end{array}$ \\
\hline Russia & 260,000 & & Rusagro & \\
\hline Russia & 221,200 & & Agrosila Group & \\
\hline Russia & 200,000 & Huge debts & Mayak & $\begin{array}{l}\text { Bankruptcy procedure, } \\
\text { criminal case }\end{array}$ \\
\hline Russia & 200,000 & & Inteko-Agro & \\
\hline $\begin{array}{l}\text { Sweden/ } \\
\text { Switzerland }\end{array}$ & 198,000 & & $\begin{array}{l}\text { Lupus Holdings } \\
\text { (Volga farming/ } \\
\text { Redland) }\end{array}$ & \\
\hline Sweden & 161,000 & $\begin{array}{l}\text { Unprofitable. Alpcot Agro } \\
\text { acquired the bankrupt } \\
\text { Landkom }\end{array}$ & Alpcot Agro & $\begin{array}{l}\text { Major change of } \\
\text { management }\end{array}$ \\
\hline Russia & 160,000 & & Pava & \\
\hline Russia & 155,000 & & Avangard-Agro & \\
\hline Russia & 164,500 & & RAV Agro-Pro & $\begin{array}{l}\text { Acquired by Czech PPF } \\
\text { Company (2011) }\end{array}$ \\
\hline Sweden & 130,100 & & Trigon Agri & \\
\hline Russia & 120,000 & Huge debts & APK-OGO & Bankruptcy procedure \\
\hline Russia & 109,500 & $\begin{array}{l}\text { A number of the holding's } \\
\text { enterprises are } \\
\text { unprofitable }\end{array}$ & Stoilenskaya Niva & $\begin{array}{l}\text { Sale of unprofitable } \\
\text { enterprises }\end{array}$ \\
\hline Russia & 100,000 & & IPF-AGRO & \\
\hline
\end{tabular}

Source: Own web research. The size of the landholdings are based on the top 25 agroholdings by Novoselov (2010), with some updates based on own web search. Estimates on the landholdings of agroholdings differ (one source (RT 2013) for instance does not mention Ivolga and ranks Prodimex (here number 2) as the largest landholder), and landholdings change rapidly, therefore this top- 25 is indicative. The agroholdings in this table all have landholdings of over $100,000 \mathrm{ha}$, but according to some of the estimations recently 32 agroholdings have holdings over 100,000 ha. 


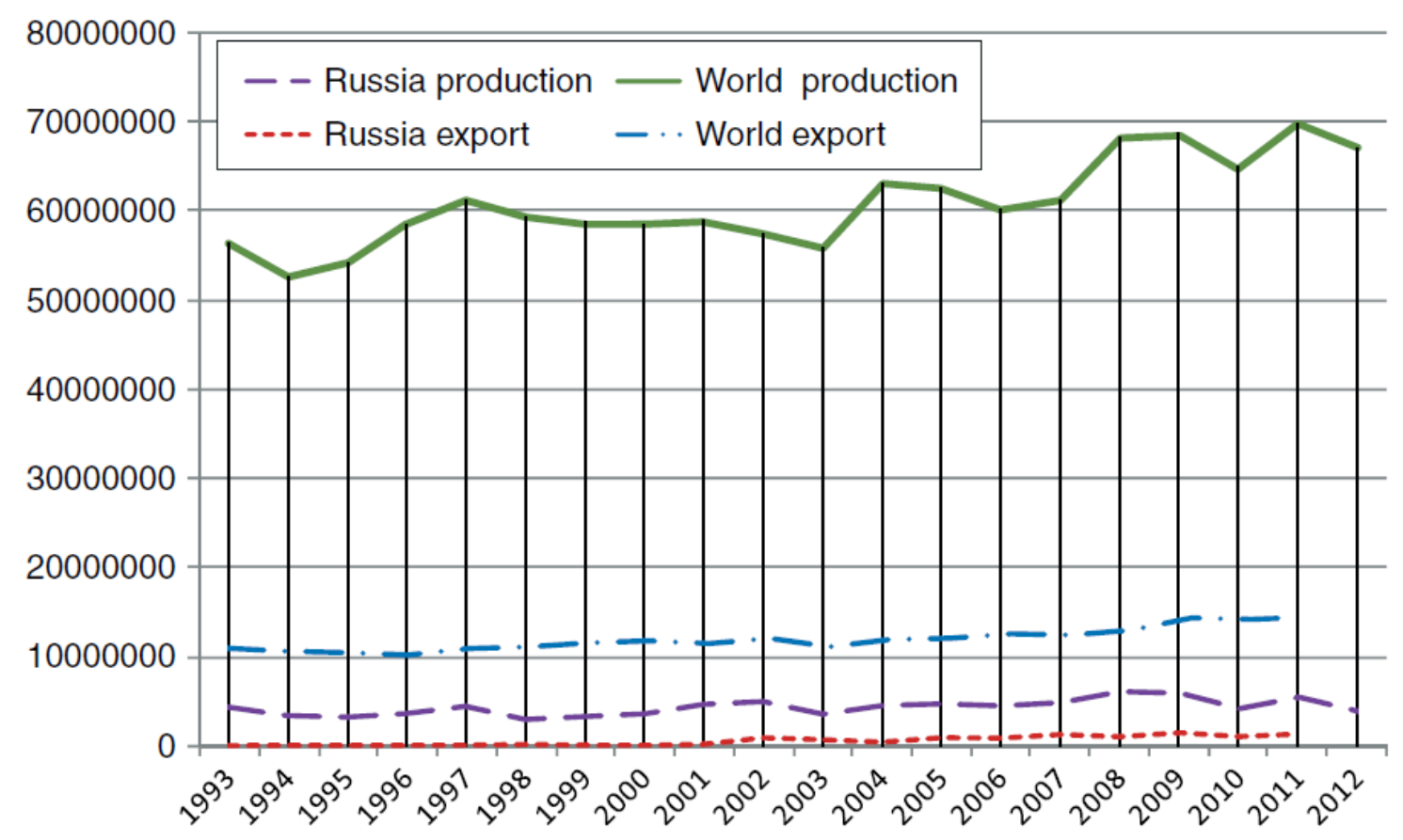

FIGURE 3. PRODUCTION AND EXPORTS OF WHEAT: RUSSIA AND the WORLD (X TONS). Source: FAOSTAT (2013a, 2013b), based on data from FAOSTAT's, Agricultural Trade domain and Agricultural Production domain. 